\title{
The effects of financialization on investment: evidence from firm-level data for the UK
}

Daniele Tori, Lecturer in Finance, The Open University Business School, and Greenwich Political Economy Research Centre, University of Greenwich, daniele.tori@open.ac.uk

Özlem Onaran, Professor of Economics and Director of Greenwich Political Economy Research Centre, University of Greenwich, London SE10 9LS, o.onaran@gre.ac.uk

Forthcoming in Cambridge Journal of Economics, acceptance date 14.10.2017, authors' accepted manuscript

\section{Abstract}

This paper estimates the effects of financialization on physical investment in the UK using panel data based on balance-sheets of publicly listed non-financial companies supplied by Worldscope for the period 1985-2013. We find robust evidence of an adverse effect of not only financial payments (interests and dividends) but also financial incomes on the rate of accumulation. The negative impacts of financial incomes from interests and dividends are particularly strong for the pre-crisis period. Our findings support the 'financialization thesis' that the increasing orientation of the non-financial sector towards financial activities is ultimately leading to lower physical investment, hence to stagnant or fragile growth, as well as long term concerns for productivity.

Keywords: Financialization, Investment, Non-financial sector, Firm data, United Kingdom.

JEL classification: C23, D22, G30. 


\section{Introduction}

This paper estimates the effects of financialization on physical investment in the UK using panel data based on balance-sheets of non-financial publicly listed companies for the period of 1985-2013. We aim at contributing to the understanding of the impact of two institutional changes, which emerged in the last decades in developed capitalist economies: a) a new regime of accumulation largely shaped around financial motives and b) the consolidation of the 'shareholder value' as the key principle in corporate governance ${ }^{1}$. The USA and the UK have been at the forefront of these changes (Lapavitsas and Powell, 2013)2. This paper aims at presenting a theoretical model and an empirical analysis of the effects of financialization on firms' investment in fixed assets in the case of the UK.

Back in the 1950s Joan Robinson (1952:86) stated that "where enterprise leads finance follows", describing a financial system that was merely supporting trajectories already planned by the productive sector. In contrast, recent structural changes in the functioning of capitalism mark the growing prominence of the 'financial motives' over the traditional productive purposes. In this sense, the picture for the UK economy, along with other developed capitalist economies, is emblematic. In the 1970 s, the share of manufacturing in value added was equal to $31 \%$ whilst the financial activities (Financial Intermediation and Real Estate -FIRE) counted for only 13\%, as shown in Figure 1. Since 1991 the share of FIRE has surpassed manufacturing, and as of 2013 the financial sector represents $31.2 \%$ of the total value added, whilst that of manufacturing dropped to $9.8 \%$. Instead of being merely a vehicle for more efficient production plans, in the last decades the financial activities have grown disproportionately compared to the financing requirements of the rest of 
the economy. This new configuration raises the question of how this imbalance affected the accumulation processes in the non-financial sector.

\section{[Figure 1]}

This tendency could be interpreted as the result of the growth of the UK (and especially London) as an international financial centre specialized in providing unique financial services to the global economic system. In this view, this potentially positive structural change would have benefited all the other economic setors. In fact, the mainstream literature asserts that financial markets facilitate the financing and the efficient allocation of investment (King and Levine, 1993; Gilchrist and Himmelberg, 1995; Beck et al., 2000; Love, 2003; Beck and Levine, 2004; Levine, 2005). However, Arestis and Demetriades (1997) warn against the robustness of these results based on cross-country evidence, which do not take into account the institutional peculiarities. Moreover, the effect of stock market development on growth is found to be weaker than that of the banking sector (Arestis et al., 2001). Recently after the 2007-2008 crash, the disproportionate growth of the financial system has been questioned in some mainstream contributions as well (Cecchetti and Kharroubi, 2012; Beck et al., 2014). In particular, Law and Singh (2014) argue that there is a 'threshold effect' in the relationship between the extension of financial resources and growth; thus the expansion of the financial system is beneficial to growth only up to a point. Recently, a similar argument has been put forward by an IMF discussion note with respect to emerging markets (Sahay et al., 2015), which argues that 'too much finance' increases both economic and financial volatility.

The Post-Keynesian literature on 'financialization' illustrates the negative impacts of expanding financial sector on the economic systems (Epstein, 2005), on 
income distribution and demand (Onaran et al., 2010; Hein, 2013), and in particular on investment (Stockhammer, 2004, 2006; Orhagnazi, 2008a; Dallery, 2009; Cordonnier and Van de Velde, 2015). 'Financialization' is a self-reinforcing socioeconomic process, which manifests itself in the growing prominence of behaviours derived from the functioning of the financial sector. A similar argument can be found in the marxist literature, for which the long-term trajectories of the economies gravitate more around the financial sector and less around the productive one (Foster, 2010). Since the 1980s, the slow down in investment and growth went along with a rise in the interest and dividend payments and share buybacks of the nonfinancial corporations (NFCs), which 'punctured' the value generated by NFCs (Duménil and Levy, 2004). As a consequence, companies experienced a significant reduction in available funds for physical investments. ${ }^{3}$

Despite an expanding theoretical literature on the effects of financialization, the empirical evidence is predominantly relegated to a macro perspective, especially in the case of physical investment. The origins of the theoretical microeconomic approach to the impact of finance on investment can be traced back to the seminal works of Fazzari and Mott (1986) and Ndikumana (1999). To the best of our knowledge only Orhangazi (2008b) and Demir (2009) analyse directly the effects of financialization on accumulation from a microeconomic perspective.

The novelty of this paper is, firstly, to provide a model of firm-level investment, which extends the Post-Keynesian model by Fazzari and Mott (1986) by integrating the effects of financial incomes as well as payments in a coherent fashion. Second, we use the Worldscope database for firm balance sheets, which allows us to build a consistent measure for companies' financial activities regarding both inflows and outflows. Third, we provide the first micro-econometric evidence for the UK on 
the effects of financialization on investment using firm data, which is an important but under-researched case. Finally, we compare the explanatory power of the PostKeynesian model to the mainstream Tobin's Q model.

The remainder of the paper is organized as follows. Section 2 discusses the key theoretical and empirical contributions in the literature. Section 3 presents the alternative models of investment to be estimated. Section 4 introduces the data and the stylized facts of our sample. Section 5 discusses the estimation methodology. Section 6 presents the estimation results. Section 7 concludes.

\section{Accumulation of fixed assets, liquidity, and financialization}

In the earlier 'accelerator investment models' (e.g. Kuh and Meyer, 1955; Evans, 1967) the capital expenditure was almost entirely explained by expected profitability measured by sales. In contrast, the early neoclassical approach modelled the firm's investment decision as a static maximization problem of discounted flows of profits over an infinite time horizon (Jorgenson, 1963; 1971). As an alternative, investment models, based on the maximization of the expected cash flows (or market value) in the presence of adjustment costs and expectations, which take the dynamic process explicitly into account, have been proposed (Chirinko, 1993). Within this group, the so-called 'Q model' of Brainard and Tobin (1968), which models investment using the Tobin's Q variable, defined as the ratio of the firm's stock market valuation to its capital replacement cost, has been widely used. However, firm-level empirical analysis has failed to provide evidence of a strong explanatory power of the Q variable (Hayashi and Inoue, 1991; Bond et al., 1992). Possible mainstream explanations focused on the bias of the stock market evaluation due to asymmetric information (Stiglitz and Weiss, 1981) and periodic 'financial bubbles' (Bond and 
Cummins, 2001; Bond et al., 2004). But more importantly, as argued by Hubbard (1998), the source of financing matter for investment.

Empirical evidence shows that cash-flows, i.e. internal funds, are important determinants of investment (Fazzari et al., 1988; Blundell et al., 1992; Brown et al., 2009). In particular, the seminal contribution by Fazzari et al. (1988) shows that fluctuations in internal finance, as reflected by cash-flows, are statistically more important than the stock market evaluation in determining the level of accumulation. Liquidity constraints play a crucial role in determining investment (Fazzari and Petersen, 1993; Chirinko and Schaller, 1995; Kadapakkam et al., 1998)

In the specific case of the UK, evidence shows that cash flow always has a signficant positive effect on accumulation, whilst the effects of the stock market evaluation and debt are mixed (Devereux and Schiantarelli, 1990; Bond and Meghir, 1994; Bond et al., 2003; Bloom et al., 2007).

The mainstream investment literature argues that companies' financing issues mainly derive from agency problems, and the development of financial markets can relax these constraints (Devereux and Schiantarelli, 1990; Love, 2003; Pawlina and Renneboog, 2005; Love and Zicchino, 2006; Guariglia and Carpenter, 2008; Bond et al., 2003). Companies' financial flows are not directly taken into account in these analyses. As a result of the transformation of the economies towards a financialized stage in the last decades, the mainstream models of investment may be misspecified due to their neglect of some important factors in the firms' financing and investment decision.

The Post-Keynesian literature offers a more holistic approach to the analysis of the effect of financial markets on investment, where NFCs are far from passive players under the control of oversized financial markets. In addition to (or even 
partially substituting) physical investments, NFCs can readily accumulate financial assets. The Post-Keynesian literature conceives the firm as a 'battlefield' for different vested interests (Stockhammer, 2006). The most visible type of internal conflict is reflected in shareholders' preference for short-term profitability, which undermines the accumulation of fixed capital (Dallery, 2009; Hein and van Treeck, 2008). There is a 'growth-profit trade-off' within the managerial decision-making process of firms (Lavoie, 1992). The increasing involvement of the NFCs in finance-related activities has to be understood primarily as a consequence of a change in the corporate governance (Lazonick and O'sullivan, 2000). From the early 1980s onwards, there has been a legitimization of the rule of maximizing the 'shareholder value' (Rappaport, 1999). While the former imperative has been to 'retain and re-invest', under the shareholder rule, to 'downsize plants and distribute earnings' is paramount. The management has to please the shareholder's requests by distributing dividends and boosting share prices through share buyback operations (De Ridder, 2009). Furthermore, financialization offers a fall back option to firms to invest in reversible short-term financial assets instead of irreversible long-term fixed assets, and thereby financial assets crowd out accumulation. This behavioural twist negatively affected the long-term investment plans.

The vast majority of the empirical literature on the impacts of financialization on investment is based on a macroeconomic framework (Stockhammer, 2004; van Treek, 2008; Orhangazi, 2008a; Arestis et al., 2012).

Regarding firm level effect of finance on investment, the seminal paper by Fazzari and Mott (1986) models the three key components of the Post-Keynesian theory of investment: a positive effect of sales (as a proxy for capacity utilization), a positive and independent effect of internal finance, i.e. 'less expensive' retained 
earnings, and a negative impact of interest expenses. ${ }^{4}$ In particular, they introduce a flow measure for interest payments to define a 'committed constraint' on the available cash flow.

In another Post-Keynesian microeconomic investment model, Ndikumana (1999) finds negative effects of both stock and flows of debt. Firm's indebtedness not only reduces the cash flow (via interest payments), but also affects the sustainability of investments.

However, Fazzari and Mott (1986) and Ndikumana (1999) do not model the impact of financial revenues, which is an important dimension of financialization. To the best of our knowledge, there are only two microeconomic papers that analyse the effects of financial incomes of NFCs. Orhangazi (2008b) finds a negative effect of financial payments and long-term debt on accumulation in the NFCs in the USA, whereas the effects of financial incomes on investment depend on the firm size and sector, with a significant negative crowding out effect for larger firms, and a positive effect for the smaller firms in the non-durables sector, indicating its dual role as a source of internal finance. Demir (2009) finds that increasing returns on financial assets relative to fixed assets reduced accumulation in the NFCs in Argentina, Mexico, and Turkey.

Building on this literature, in the next section we describe the specifications of different models of investment, by comparing a basic model vis-à-vis a full specification which takes explicitly into account the effects of financialization including both financial incomes and payments. 


\section{Alternative models of investment}

Within the Post-Keynesian theory capital accumulation is an intrinsically dynamic process (Kalecki, 1954; Lopez and Mott, 1998). Physical investment is an irreversible phenomenon. There is a path dependency that link past and future levels of accumulation, as confirmed by the previous empirical literature (Ford and Poret, 1991; Kopcke and Brauman, 2001; Orhangazi, 2008b; Arestis et al., 2012). Therefore, in all the models to be estimated, we include the lagged investment. Also all other explanatory variables are lagged in order to depict the 'adjustment processes'.

To analyse the potential effects of financialization, we start with a basic investment model based on Fazzari and Mott (1986). Next, by progressively enriching this basic version, we present our final model of 'financialized investment'. Equation (1) presents the basic model, where the rate of accumulation, $I / K$, is:

$\left(\frac{I}{K}\right)_{i t}=\beta_{0}+\beta_{1} \sum_{j=1}^{2}\left(\frac{I}{K}\right)_{i t-j}+\beta_{2} \sum_{j=1}^{2}\left(\frac{\pi-C D}{K}\right)_{i t-j}+\beta_{3} \sum_{j=1}^{2}\left(\frac{S}{K}\right)_{i t-j}+\beta_{4} \sum_{j=1}^{2}\left(\frac{i_{D}}{K}\right)_{i t-j}+\beta_{t}+\varepsilon_{i t}$

where $I$ is the gross addition to fixed assets, $K$ is the net capital stock, $\pi$ is operating income, $\mathrm{CD}$ are cash dividends, $(\pi-C D)$ identifies the retained earnings, $S$ is net sales, $i_{D}$ is the interest expenses on debt; all variables are normalized by $K$ in order to control for firm size. ${ }^{5} i$ is the firm index. $\beta_{t}$ identifies a set of time-dummies to control for unobservable time-specific effects common to all firms, whilst the standard disturbance term $\varepsilon_{i t}$ captures firm-specific fixed effects and idiosyncratic shocks. All variables are introduced in first and second lags to reflect the time consideration in the investment plans. The retained earnings/fixed assets ratio is a measure of the profit rate, the sales/fixed assets ratio is a proxy reflecting capacity utilization, whilst interest expenses reflect the firm-level cost of capital. We expect 
positive effects of the lagged accumulation rate, retained earnings, and sales on investment. In contrast, we expect the impact of interest payments (or 'cash commitments') to be negative.

In this basic model cash dividends are conceived as simply a reduction of available internal funds. However, in developed financialized capitalist systems the distributed dividends may have a further effect, reflecting behavioural changes due to the 'shareholder value orientation' (henceforth SVO) as suggested by Lazonick and O’Sullivan (2000). In addition, as argued by Boyer (2000) among others, financial markets and institutions considerably raised the profitability targets imposed on management. As a consequence, the spectrum of the investments projects considered as sufficiently profitable to be implemented has been reduced. Hence, a considerable portion of the available cash flow has been made available for the accumulation of financial assets and/or dividend payments. For these reasons, equation (2) introduces this further effect of cash dividends payments as a ratio to $K(C D / K)$ :

$$
\left(\frac{I}{K}\right)_{i t}=\beta_{0}+\beta_{1} \sum_{j=1}^{2}\left(\frac{I}{K}\right)_{i t-j}+\beta_{2} \sum_{j=1}^{2}\left(\frac{\pi-C D}{K}\right)_{i t-j}+\beta_{3} \sum_{j=1}^{2}\left(\frac{S}{K}\right)_{i t-j}+\beta_{4} \sum_{j=1}^{2}\left(\frac{i_{D}}{K}\right)_{i t-j}+\beta_{5} \sum_{j=1}^{2}\left(\frac{C D}{K}\right)_{i t-j}+\beta_{t}+\varepsilon_{i t}
$$

In the light of the macroeconomic Post-Keynesian literature, we expect an adverse effect of $\mathrm{CD} / \mathrm{K}$ on investments. We recognize that the rise in dividend payments can as also be the consequence of the process of financialization, and deceleration of accumulation, and therefore treat this variable as endogenous, as we discuss in more detail below in the section on estimation methodology.

Furthermore, not only do NFCs use part of their funds to pay interest and dividend to the financial sector, but they can also more than before pursue non- 
operating financial investment themselves, thus receiving financial incomes. Therefore, in equation (3) we include the sum of interests and dividends received by the NFCs $\left(\pi_{F}\right)$ as a ratio to $K$ as an additional variable ${ }^{6}$ :

$$
\left(\frac{I}{K}\right)_{i t}=\beta_{0}+\beta_{1} \sum_{j=1}^{2}\left(\frac{I}{K}\right)_{i t-j}+\beta_{2} \sum_{j=1}^{2}\left(\frac{\pi-C D}{K}\right)_{i t-j}+\beta_{3} \sum_{j=1}^{2}\left(\frac{S}{I}\right)_{i t-j}+\beta_{4} \sum_{j=1}^{2}\left(\frac{i_{D}}{K}\right)_{i t-j}+\beta_{5} \sum_{j=1}^{2}\left(\frac{C D}{K}\right)_{i t-j}+\beta_{6} \sum_{j=1}^{2}\left(\frac{\pi_{F}}{K}\right)_{i t-j}+\beta_{t}+
$$

Theoretically, the sign of the effect of financial incomes on investment is ambiguous. On the one hand, they may have a positive impact on the accumulation of fixed assets by easing the liquidity constraint faced by firms. In particular, this can be the case for smaller companies, which are more likely to experience liquidity restrictions compared to larger corporations. On the other hand, financial activities can also be detrimental to physical accumulation, since NFCs will be attracted by short-term, reversible financial investment, instead of engaging in long-term, irreversible physical investment.

Finally, equation (4) below presents our general model of financialized investment:

$$
\left(\frac{I}{K}\right)_{i t}=\beta_{0}+\beta_{1} \sum_{j=1}^{2}\left(\frac{I}{K}\right)_{i t-j}+\beta_{2} \sum_{j=1}^{2}\left(\frac{\pi-C D}{K}\right)_{i t-j}+\beta_{3} \sum_{j=1}^{2}\left(\frac{S}{K}\right)_{i t-j}+\beta_{4} \sum_{j=1}^{2}\left(\frac{F}{K}\right)_{i t-j}+\beta_{5} \sum_{j=1}^{2}\left(\frac{\pi_{F}}{K}\right)_{i t-j}+\beta_{t}+\varepsilon_{i t}
$$

Here we introduce a composite measure for outward financialization, $F$, which is the sum of interest and dividend payments (as a ratio to $K$ ), capturing a) the liquidity effect of interest payments, and b) the additional behavioural effect of the SVO. In brief, $F$ reflects the financial outflows, while $\pi_{F}$ reflects the financial inflows.

Furthermore, in order to test the different effect of financial payments in small vs. large companies, we estimate an extended version of Model (4) as, 


$$
\begin{aligned}
\left(\frac{I}{K}\right)_{i t}=\beta_{0}+ & \beta_{1} \sum_{j=1}^{2}\left(\frac{I}{K}\right)_{i t-j}+\beta_{2} \sum_{j=1}^{2}\left(\frac{\pi-C D}{K}\right)_{i t-j}+\beta_{3} \sum_{j=1}^{2}\left(\frac{S}{K}\right)_{i t-j}+ \\
& +\beta_{4} \sum_{j=1}^{2}\left(\frac{F}{K}\right)_{i t-j}+\beta_{5} \sum_{j=1}^{2}\left(\frac{\pi_{F}}{K}\right)_{i t-j}+\beta_{6} \sum_{j=1}^{2}\left(\frac{\pi_{F}}{K} \cdot D_{T A 25}\right)_{i t-j}+\beta_{7} D_{T A 25 i t-j}+\beta_{t}+\varepsilon_{i t}
\end{aligned}
$$

where the dummy variable $D_{\text {TA25 }}$ takes the value 1 if the average total assets of company $i$ lies in the lower 25 percentile of the distribution, and takes the value 0 otherwise. The dummy is interacted with the financial incomes. While $\beta_{5}$ is the effect of financial incomes in large companies, $\beta_{5}+\beta_{6}$ capture the effect of financial incomes in smaller companies.

With equations (4) and (4a) we aim at introducing a full model of firm-level investment that is coherent with the Post-Keynesian tradition of investment analysis, and that a) takes into account the inherent irreversibility of physical investment, b) controls for the independent effect of profitability and demand, c) highlights the effects of financial relations, d) makes a clear distinction between operating and nonoperating activities, and e) treats financial outflows and inflows, i.e. both outward and inward financialization, as fundamental determinants. ${ }^{7}$

\section{Data and stylized facts}

We extracted our data from the Worldscope database of publicly listed firm's balance sheets, which contains standardized accounting information about not only investment, sales, profits, interest and dividend payments but also companies' financial incomes. Standardized data on financial payments and, in particular, financial incomes are difficult to find; our database allows us to have a comprehensive variable for our estimations. Worldscope database has been acknowledged as a valuable source in the literature on firm-level investment analysis 
(e.g. Cleary 1999; Pawlina and Renneboog, 2005; Love, 2003; Love and Zicchino, 2006).

We use data for all active and inactive, publicly listed NFCs in the UK (thus excluding financial firms identified by the primary SIC codes from 6000 to 6799). ${ }^{8}$ Our data are annual for the period of $1985-2013 .{ }^{9}$ We found a high correlation between our variables and the corresponding macroeconomic data. ${ }^{10}$ Tables $3 \mathrm{~A}$ and 4A in the Appendix provide summary statistics for the total economy and manufacturing sector.

It is well-known that the presence of outliers usually characterizes firm-level data. To prevent biased estimations, we apply a data screening process, by excluding extreme outlier observations from the sample. First, we select firms that have at least three consecutive observations for the dependent variable, which is also required for econometric purposes (Roodman, 2009). Second, we drop all the companies with a permanent negative mean operating income. Finally, we exclude observations in the upper and lower $1 \%$ of each variable's distribution. ${ }^{11}$

Next we present the stylized facts of our sample. As can be seen in Figure 2, the rate of accumulation of fixed assets in the UK's NFCs decreased substantially during the early 1990s, and has only partially recovered, albeit not back to its peak level, with further declines during the Great Recession.

[Figure 2]

Overall, the rate of accumulation has remained stagnant around an average of 0.25 for the whole period. Compared to the peak in $1988(0.32)$, the rate is lower (0.26) in 2013. The stagnation in the manufacturing sector (dashed line) is stronger, 
as investment has not recovered much after the 1990s recession, with the rate of accumulation being the same in 2013 as in $1985(0.22)$.

Figure 3 shows the trends in the rate of accumulation and the operating income (as a ratio to $K$ ). From the start of the recovery in 1992 onwards, the rate of accumulation increases along with the operating income; however the rise in operating income is stronger with respect to investment. Furthermore, from 2004 on, investment stagnates despite an increasing profit rate. ${ }^{12}$

\section{[Figure 3]}

Figure 4 shows the ratio of investment (addition to fixed assets) to operating income; i.e. the rate of reinvestment, and the stock of financial assets as a ratio to fixed assets. There has been a clear decline of the operating income devoted to the enlargement of NFCs' core activities from $80-90 \%$ in the 1980 s to $40-50 \%$ in the last decade. Despite the partial recovery of investments since 1992, the rate of reinvestment continued to decline. In sharp contrast, the stock of financial assets increased substantially, reaching $90 \%$ as a ratio to fixed capital in the late 1980 s, and a level more than three times the fixed assets before the crisis in 2008 . The financial crisis in 2008 has led to only a slight fall in the value of the financial assets. As shown in figure 5, the substantial involvement in the accumulation of financial assets resulted in increasing non-operating income for the NFCs, which again declined briefly after the 2007-2008 crisis, and then totally recovered in 2013.13

\section{[Figure 4]}

[Figure 5] 
Finally, Figure 6 shows the financial payments of the NFCs in the form of interests on debt and dividends paid to the shareholders, which have increased substantially since the mid-1990s. From 1985 to 2008 financial payments $\left(C D+i_{D}\right)$ as a ratio to total fixed capital increased from $16 \%$ in 1985 to $42 \%$ in 2008 . The financial exposition of NFCs entails a significant reduction of internal funds. After the Great Recession interest paid on debt diminishes, whereas dividends paid maintain their increasing trend after a brief period of fall.

[Figure 6]

In conclusion, the stylized facts show a) a stagnant rate of accumulation b) a declining rate of reinvestment of operating income c) an increase in the overall degree of financialization in terms of financial assets, incomes as well as payments.

\section{Estimation methodology}

Equations 1-4 presented in Section 3 are estimated using a dynamic panel-data model including two lags of the accumulation rate as explanatory variables. As explained in section 3, investment is an intrinsically dynamic phenomenon.

In dynamic panel data models, the unobserved panel-level effects are correlated with the lagged dependent variables. As a consequence, standard estimators (e.g. Ordinary or Generalized Least Squares) would be inconsistent. Therefore, we estimate our models using a difference-GMM estimator (Arellano and Bond, 1991). This methodology is suitable for analyses based on a 'small time/large observations' sample. ${ }^{14} \mathrm{GMM}$ is a powerful estimator for analyses based on firm-level data mainly for three reasons (Roodman, 2009). First, GMM is one of the best 
techniques to control for all sources of endogeneity between the dependent and explanatory variables, by using internal instruments, namely the lagged levels of the explanatory variables, which allows us to address dual causality, if rising financial payments and incomes is also a consequence of the slowdown in the capital accumulation. The instrument set consists of instruments that are not correlated with the first difference of the error term, but correlated with the variable we are estimating. Second, by first-differencing variables, this estimator eliminates companies' unobservable fixed effects. Third, GMM can address autocorrelation problems. We apply two tests to assess the appropriateness of the instrument sets, and lag structures. First, we check for second-order serial correlation with the Arellano-Bond test (Arellano and Bond, 1991). Second, we verify the validity of the instruments sets through the Hansen test. ${ }^{15}$ In all models, the lagged dependent variable enters the instrument set as endogenous while all other explanatory variables enter as predetermined regressors. Consistently, the instrument sets include the second and third lags of the lagged dependent variable, and the first and second lags of the other lagged explanatory variables. We test the joint significance of the time dummies using a Wald test.

All the variables are in logarithmic form to allow for non-linear relationships between the dependent and the explanatory variables. Furthermore, the logarithmic scale enables us to reduce the disturbances coming from the presence of heteroskedasticity.

Our estimation procedure for each model is based on a 'general-to-specific' strategy, where we arrive at a model with only significant variables. Robust standard errors are calculated through a two-step procedure after a finite-sample correction (Windmeijer, 2005). 


\section{Estimation results}

This section presents our estimation results. Column 1 of Table 1 shows the estimated coefficients for Model (1). As expected, the lagged level of accumulation, sales, and retained earnings have positive effects on investment, while interest expenses have a significant negative effect. Our results for the UK are in line with the findings of Fazzari and Mott (1986) for the USA.

Column 2 shows the results for Model (2). We find a significant negative impact of $C D$ reflecting the SVO. Thus, the distribution of dividends not only decreases available liquidity but also has a further negative behavioural effect on accumulation.

Column 3 shows the results for Model (3). Income from the NFCs' financial operations has an adverse effect on accumulation, along with a negative effect of interest expenses. Cash dividend payments do have a negative but statistically insignificant effect.

Finally, Column 4 shows the results for the general model extended with a variable reflecting aggregated shareholder/lenders value orientation as in Model 4. In addition to the 'financial puncturing' due to the external funding (banking sector and shareholders), total financial incomes in the form of interests and dividends received have a significant and negative impact on physical accumulation as well. Thus, financial investment crowds-out physical investment. All other variables have the expected signs.

In column 5 we present an extended version of model 4 including the stock market evaluation (Tobin's Q) to test the robustness of our results to the inclusion of this widely used variable in the mainstream literature. ${ }^{16}$ Tobin's $Q$ has a statistical significant and positive effect, and the estimated signs and even magnitudes of the other coefficients remain robust. 


\section{[Table 1]}

Finally, Column 6 of Table 1 presents the results for Model ( 4 a), a revised version of Model (4) in order to capture the different effect of financial incomes with respect to the companies' sizes. As expected, financial incomes have a significant positive effect on physical accumulation in the smaller companies, with an elasticity of 0.11 . This finding is in line with the microeconomic evidence for the USA (Orhangazi, 2008b). The effect of financial incomes in the large companies is still negative.

Next, we test the robustness of our results. First, we estimate model 4 for the pre-crisis period of 1985-2007 only. The Great Recession affected both the real and financial sides of the economies. As we have seen in section 5, financial incomes experienced a sudden fall in 2008. Column 1 in Table 2 presents the results. The signs of the coefficients of both financial incomes and payments are negative also for this period. Furthermore, the coefficient of financial incomes is more than double compared to that in the full period.

Second, we control also for another break in the UK economy, namely the early 1990s recession, and estimate our model for the period 1992-2007. The results reported in Column 2 in Table 2 are similar to the ones based on the estimation for the 1985-2007 period. The only main difference is a stronger negative effect of the financial payments.

[Table 2] 
Third, we estimated our final model using the raw-dataset to check the robustness to the inclusion of the outliers for the period of 1985-2013. As can be seen in Column 3 of Table 2, the results are robust. ${ }^{17}$

Fourth, we performed a robustness check by excluding the public services, transportation, and utilities sectors (primary SIC codes from 4011 to 4971 and 9111) with a high degree of governmental involvement, since these companies may behave differently. As can be seen in Column 4 of Table 2, our estimation results are again robust.

Next we estimated Model (4) for the manufacturing sector only. Table 3 presents the results for different periods.

\section{[Table 3]}

We focus on manufacturing companies for two reasons. First, our results are better comparable with other findings since a considerable part of the empirical analyses about firm-level investment is based on manufacturing. Second, as we have seen, the share of the manufacturing sector in the UK economy has decreased sharply (Figure 1). It is worthwhile to test if financialization has led to a finance-led deindustrialization. The results in Column 1 in Table 3 are similar to the ones for the whole NFCs sample. Outward financialization, as well as financial incomes, had adverse effects on accumulation also in the manufacturing sector. As before, the magnitudes of these adverse impacts increase for both the pre-2007, and the intracrises periods (Columns 2 and 3).

Finally, we present the economic significance of our estimates in Table $4 .{ }^{18}$ As argued by Ziliak and McCloskey (2008), it is important to address the potential 
discrepancy between statistical and substantive significance of the estimated elasticities. We thus computed the 'economic significance' of our estimates in order to provide a more reliable measure about the magnitude of the effects. We compute the long-run elasticities by dividing each short-run elasticity by one minus the coefficient of the lagged dependent variable. Multiplying the long-run coefficient by the actual cumulative change in each variable for the estimation period, we get the corresponding economic effect.

Sales (capacity utilization) have been the main determinant of accumulation while retained profits had a lower impact. Financial payments, i.e. outward financialization (the composite variable for interest payments and SVO) had a substantial negative impact on physical investment. The rate of accumulation would have been $8.5 \%$ higher without the rise in financial payments. Financial incomes, inward financialization, had an adverse effect as well, leading to a decline in the accumulation rate by $3.6 \%$. The negative impact of outward financialization during the pre-crisis phase (1985-2007) is substantially larger $(-11.4 \%)$, due to a higher long-run coefficient.

\section{[Table 4]}

Unsurprisingly, the 2008 crisis has strongly reduced the financial incomes of NFCs. The cumulative increase in financial incomes before the financial crisis is much higher (1.233) than the increase in the full period (0.751). ${ }^{19}$ Additionally, the long-run elasticity of financial income is stronger in this period $(-0.109)$. Hence, in the precrisis phase financial incomes have had a larger negative impact on accumulation. The accumulation rate would have been $13.5 \%$ higher without an increase in financial incomes. 
Also in the manufacturing sector, the sharp rise in financial payments reduced the rate of accumulation by $13.5 \%$ from 1985 to 2013 , and by almost $20 \%$ before the crisis. The 2008 financial crisis led to a decrease in the financial incomes of manufacturing, which in turn had a positive economic impact on the rate of accumulation in manufacturing companies by $10.2 \%$. Given the higher elasticities, financial payments had the strongest negative economic effects in both time periods.

\section{Conclusion}

This paper presents empirical evidence on the effects of financialization on firm-level investment in the publicly listed NFCs in the UK based on a dynamic panel data model. Our results show that financialization, depicted as the increasing orientation towards external financing, and the internal substitution of fixed accumulation by financial activity, had a fundamental role in suppressing investment in the NFCs in the UK. This is even more evident in the period before the financial crash, and especially for the manufacturing sector. The availabilty of internal funds constraints the investment decision. On the one hand, the increase in financial payments for external finance and to favor the shareholders (interest and dividends) reduce the NFCs internal funds, and thus accumulation. On the other hand, the negative crowding-out effects of financial investment on accumulation more than offset the gains from relaxing the cash-flow constraint. Financial incomes have a positive effect on investment only for the smaller companies.

In the UK NFCs, the rate of accumulation would have been higher without the rise in interest and dividend payments as well as financial incomes. The negative effects of financialization have been stronger in the pre-crisis period. The physical accumulation in manufacturing sector suffered even more experiencing a finance-led 
deindustrialisation. In particular, for the pre-crisis period in manufacturing we find that the adverse effects of financial payments and financial incomes almost entirely offset the positive impacts due to increasing sales and retained profits. It is important to stress that these results are based on the specific sample of publicly listed companies.

These results for the UK provide support to the theoretical arguments regarding the negative effects of financialization and confirm previous empirical findings at the macro and microeconomic levels for other countries. In particular, although not fully comparable, our results confirm previous findings at the microeconomic level for the USA (Orhangazi, 2008b), as well as at the macroeconomic level for the USA and European countries (see in particular Stockhammer, 2004 and van Treeck, 2008).

The increasing interrelations between the financial markets and the NFCs are progressively reducing fixed capital accumulation, and thus growth. These results contrast with the mainstream arguments regarding the beneficial effects of financial deepening.

To reach a stable and vigorous dynamic of investment, a de-financialization of the non-financial sector is desirable. This requires an extended regulation of companies' non-operating financial activities along with financial regulation. The robust connection between past and present levels of accumulation increases the potential effectiveness of de-financialization economic policies.

Clearly our analysis does not exhaust the need for a deeper analysis about financialization of the NFCs, and further research is needed to assess the multifaceted feature of this phenomenon. In particular, the investigations of the determinants of 
companies' 'financial accumulation', as well as the sources of businesses' financial assets are important questions for future research. 


\section{References}

Arellano, M., Bond, S. (1991). "Some tests of specification for panel data: Monte Carlo evidence and an application to employment equations." The review of economic studies 58(2):277-297.

Arestis, P., González, A. R., Dejuán, Ó. (2012). “Modelling accumulation: A theoretical and empirical application of the accelerator principle under uncertainty". European Journal of Economics and Economic Policies: Intervention 9(2):255-276.

Arestis, P. and Demetriades, P.O. (1997), "Financial Development and Economic Growth: Assessing the Evidence", Economic Journal, 107(442):783-799.

Arestis, P., Demetriades, P.O. and Luintel, K.B. (2001), "Financial Development and Economic Growth: The Role of Stock Markets", Journal of Money, Credit and Banking, 33(1):16- 41.

Beck T., Levine R., Loayza N. (2000). "Finance and the sources of growth". Journal of Financial Economics 58:261-300.

Beck, T., Levine, R. (2004). “Stock markets, banks, and growth: Panel evidence.” Journal of Banking and Finance 28:423-442.

Beck, T., Degryse, H., Kneer, C. (2014). "Is more finance better? Disentangling intermediation and size effects of financial systems." Journal of Financial Stability 10:50-64.

Bloom, N., Bond, S., \& Van Reenen, J. (2007). "Uncertainty and investment dynamics." The Review of Economic Studies 74(2):391-415. 
Blundell, R.; Bond, S.; Devereux, M.; Schiantarelli, F. (1992). "Investment and Tobin's $<i>Q$ $</ i>$ : Evidence from company panel data". Journal of Econometrics 51(1):233-257.

Boyer, R. (2000). "Is a financed-led growth regime a viable alternative to Fordism? A preliminary analysis". Economy and Society, 29(1):111-145.

Bond S. R., Elston J. A., Mairesse J., Mulkay B. (2003). "Financial Factors and Investment in Belgium, France, Germany, and the United Kingdom: a Comparison Using Company Panel Data". The Review of Economics and Statistics 85(1):153-16.

Bond, S. R. and Cummins, J. G. (2001). "Noisy share prices and the $Q$ model of investment". IFS Working Papers, No.01/22.

Bond, S., \& Meghir, C. (1994). "Dynamic investment models and the firm's financial policy". The Review of Economic Studies 61(2):197-222.

Bond, S., Klemm, A., Newton-Smith, R., Syed, M., Vlieghe, G. (2004). "The roles of expected profitability, Tobin's $Q$ and cash flow in econometric models of company investment". IFS Working Papers, No. 04/12.

Brainard, W. C., Tobin, J. (1968). "Pitfalls in financial model building". American Economic Review 58(2):99-122.

Brown, J., Fazzari, S. and Petersen, B. (2009). "Financing innovation and growth: cash flow, external equity and the 1990s R\&D boom". The Journal of Finance 64(1):151-185. 
Cecchetti, S.G., Kharroubi, E. (2012). "Reassessing the Impact of Finance on Growth". BIS Working Paper Series, No. 381.

Chirinko, R. S. (1993). "Business fixed investment spending: Modelling strategies, empirical results, and policy implications". Journal of Economic Literature 31:1875-1911.

Chirinko, R. S., Schaller H. (1995). "Why Does Liquidity Matter in Investment Equations?". Journal of Money, Credit and Banking 27(2):527-548.

Chung, K., Pruitt., S. (1994). “A Simple Approximation of Tobin's Q". Financial Management 23:70-74.

Cleary, S. (1999). "The relationship between firm investment and financial status". The Journal of Finance 54(2):673-692.

Cordonnier, L., Van de Velde F. (2015). "The demands of finance and the glass ceiling of profit without investment". Cambridge Journal of Economics 39(3):871-885.

Dallery, T. (2009). "Post-Keynesian theories of the firm under financialization." Review of Radical Political Economics 41(4):492-515.

De Ridder, A. (2009). "Share repurchases and firm behaviour". International Journal of Theoretical and Applied Finance 12(05):605-631.

Demir, F. (2009). "Financial liberalization, private investment and portfolio choice: financialization of real sectors in emerging markets". Journal of Development Economics 88(2):314-324. 
Devereux, M., Schiantarelli, F. (1990). “Investment, financial factors, and cash flow: Evidence from UK panel data." In "Asymmetric information, corporate finance, and investment", pp. 279306. Chicago: University of Chicago Press.

Duménil, G., Levy, D. (2004). "Capital Resurgent: Roots of the Neo-Liberal Revolution". Harvard University Press, Cambridge (USA).

Epstein, G. A. (2005). "Introduction: Financialization and the World Economy" in Epstein G. A. (ed.), "Financialization and the World Economy". Cheltenham: Edward Elgar.

Evans, M. K. (1967). "A study of industry investment decisions". The Review of Economics and Statistics 49:151-164.

Fazzari, S. M., Hubbard, R. G., Petersen, B. C. (1988). "Financing constraints and corporate investment". Brookings Papers on Economic Activity 1:141-195.

Fazzari, S. M., Petersen, B. C. (1993). "Working capital and fixed investment: new evidence on financing constraints". The RAND Journal of Economics 24(3):328-342.

Fazzari, S., Mott, T., (1986). "The investment theories of Kalecki and Keynes: an empirical study of firm data, 1970-1982". Journal of Post-Keynesian Economics 9(2):171-187.

Ford, R., Poret, P. (1991). "Business investment: recent performance and some implications for policy". OECD Economic Studies 16:79-131.

Foster, J. B. (2010). “The Financialization of Accumulation”. Monthly Review 62(5):1-17. 
Gilchrist, S., Himmelberg, C. P. (1995). "Evidence on the role of cash flow for investment." Journal of monetary Economics, 36(3):541-572.

Guariglia, A. and Carpenter, R. (2008). "Cash-flow, investment, and investment opportunities: new tests using UK Panel data", Journal of banking finance 32(9):1894-1906.

Hayashi, F., Inoue T. (1991). "The relation between firm growth and $q$ with multiple capital goods: theory and evidence from Japanese panel data". Econometrica 59(3):731-754.

Hein, E. (2013). "Finance-dominated capitalism and re-distribution of income: a Kaleckian perspective". Cambridge Journal of Economics, bet038.

Hein, E., van Treeck, T. (2008). "Financialisation in Post-Keynesian models of distribution and growth-a systematic review" (No. 10). IMK at the Hans Boeckler Foundation, Macroeconomic Policy Institute.

Holtz-Eakin, D., Newey, W., Rosen, H. S. (1988). "Estimating Vector Autoregressions with Panel Data." Econometrica 56(6):1371-95.

Hubbard, R. G. (1998). "Capital-market imperfections and investment". Journal of Economic Literature 36(1):193-225.

Jorgenson, D. W. (1963). "Capital Theory and Investment Behavior." American Economic Review, Papers and Proceedings 53:247-259.

Jorgenson, D. W. (1971). "Econometric studies of investment behavior: a survey". Journal of Economic Literature 9(4):1111-1147. 
Kadapakkam, P. R., Kumar, P. C., Riddick, L. A. (1998). "The impact of cash flows and firm size on investment: The international evidence". Journal of Banking \& Finance 22(3):293- 320.

Kalecki, M. (1954). “Theory of Economic Dynamics”. London: George Allen and Unwin.

King, R. G., Levine, R. (1993). "Finance and growth: Schumpeter might be right". Quarterly Journal of Economics 108(3):7I 7-737.

Kliman, A., Williams S.D. (2014). “Why 'financialisation' hasn't depressed US productive investment". Cambridge Journal of Economics, beu033.

Kopcke, R. W., Brauman, R. S. (2001). “The performance of traditional macroeconomic models of businesses' investment spending". New England Economic Review, pp. 3-39.

Krippner, G. R. (2005). "The financialization of the American economy". Socio-Economic Review, 3(2):173-208.

Kuh, E. and Meyer, J. (1955). "Acceleration and related theories of investment: an empirical inquiry". Review of Economics and Statistics 38(3):217-230.

Lapavitsas, C. (2009). “Financialised Capitalism: Crisis and Financial Expropriation”. Historical Materialism, 17(2):114-148.

Lapavitsas, C., Powell, J. (2013). “Financialisation varied: a comparative analysis of advanced economies. " Cambridge Journal of Regions, Economy and Society 6:359-379.

Lavoie, M. (1992). "Foundations of post-Keynesian economic analysis." Cheltenham: Edward Elgar. 
Law, S. H., Singh, N. (2014). "Does too much finance harm economic growth?" Journal of Banking \& Finance 41(1):36-44.

Lazonick, W., O'sullivan, M. (2000). "Maximizing shareholder value: a new ideology for corporate governance". Economy and society 29(1):13-35.

Lindenberg, E., Ross, S. (1981). "Tobin's q and industrial organization”. Journal of Business $54: 1-32$

Lopez, J., \& Mott, T. (1999). "Kalecki versus Keynes on the Determinants of Investment." Review of Political Economy, 11(3):291-301.

Love, I. (2003). "Financial development and financing constraints: International evidence from the structural investment model." Review of Financial studies 16(3):765-791.

Love, I., Zicchino, L. (2006). "Financial development and dynamic investment behavior: Evidence from panel VAR." The Quarterly Review of Economics and Finance 46(2):190-210.

Meyer, J. R., Kuh, E. (1966). "The investment decision: An empirical study". Cambridge: Harvard University Press.

Ndikumana L. (1999). "Debt Service, Financing Constraints, and Fixed Investment: Evidence from Panel Data". Journal of Post Keynesian Economics 21(3):455-478.

Onaran, Ö., Stockhammer, E., Grafl, L. (2010). "Financialisation, income distribution and aggregate demand in the USA". Cambridge Journal of Economics 35(4):637-661. 
Orhangazi, Ö. (2008a). "Financialization and the US Economy”. Cheltenham: Edward Elgar.

Orhangazi, Ö. (2008b). "Financialisation and capital accumulation in the non-financial corporate sector: A theoretical and empirical investigation on the US economy: 1973- 2003". Cambridge Journal of Economics 32(6):863-886.

Pawlina, G., Renneboog, L. (2005). "Is Investment-Cash Flow Sensitivity Caused by Agency Costs or Asymmetric Information? Evidence from the UK". European Financial Management 11(4):483-513.

Rappaport, A. (1999). “Creating shareholder value: a guide for managers and investors". New York: Simon and Schuster.

Robinson, J. (1952)."The Generalization of the General Theory". In "The rate of interest, and other essays", pp. 67- 142. London: Macmillan.

Roodman, D. (2009). "How to do xtabond2: An introduction to difference and system GMM in Stata". Stata Journal 9(1):86-136.

Sahay, R., Čihák, M., Papa N’Diaye, A., Barajas, R. B., Ayala, D., Gao, Y., Yousefi, S. R. (2015). "Rethinking Financial Deepening: Stability and Growth in Emerging Markets." IMF discussion note SDN/15/08.

Stiglitz, J. E., Weiss, A. (1981). "Credit rationing in markets with imperfect information". American Economic Review 71:393-410. 
Stockhammer E. (2004). "Financialisation and the slowdown of accumulation". Cambridge Journal of Economics 28(5):719-741.

Stockhammer E. (2006). "Shareholder value orientation and the investment-profit puzzle". Journal of Post Keynesian Economics 28(2):193-215

van der Zwan, N. (2014). "Making sense of financialization". Socio-Economic Review, 12(1):99-129.

van Treeck, T. (2008). "Reconsidering the investment-profit nexus in finance-led economies: an ardl-based approach". Metroeconomica 59(3):371-404.

Windmeijer, F. (2005). "A finite sample correction for the variance of linear efficient two-step GMM estimators". Journal of econometrics 126(1):25-51.

Ziliak, S. and McCloskey, D. (2008) “The Cult of Statistical Significance: How the Standard Error Costs Us Jobs, Justice, and Lives". Ann Arbor: University of Michigan Press 


\section{Figures and Tables}

Figure1. Value added in the financial and manufacturing sectors as a ratio to total value added in the UK (\%)

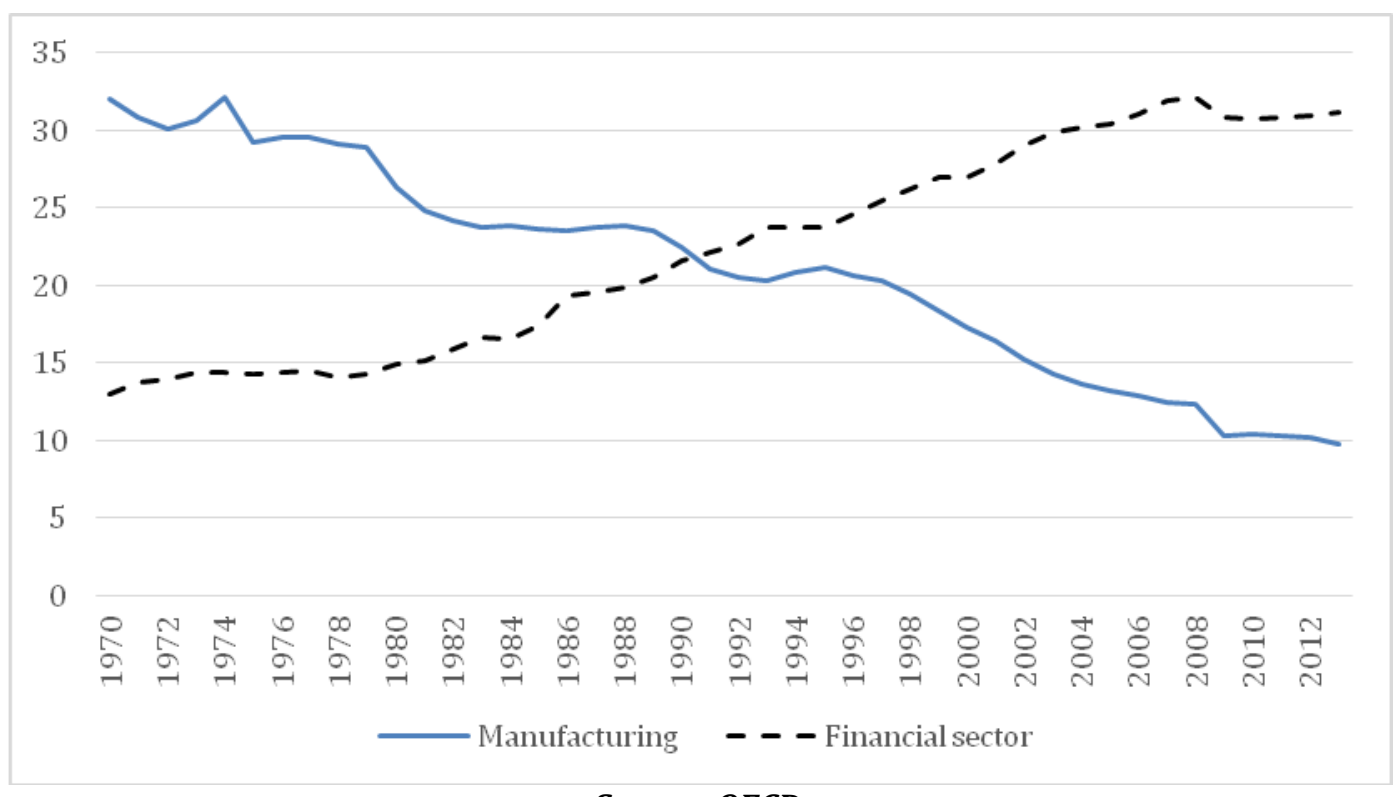

Source: OECD

Figure 2. Rate of accumulation $(I / K)$ in NFCs in all sectors and in Manufacturing in the UK

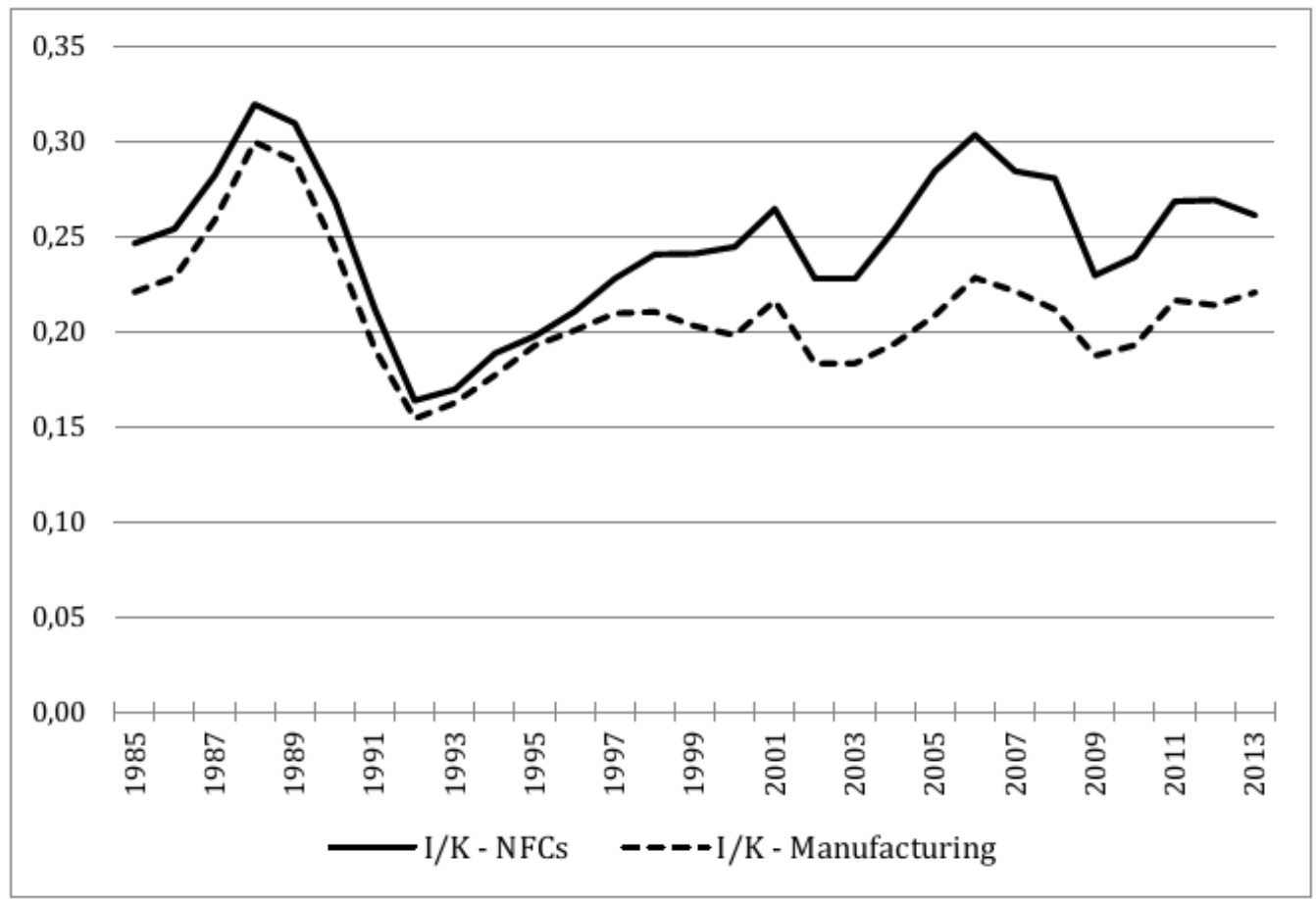

Source: authors' calculation based on Worldscope data. 
Figure 3. Rate of accumulation $(I / K)$ and operating income $(\pi / K)$ in NFCs, the UK

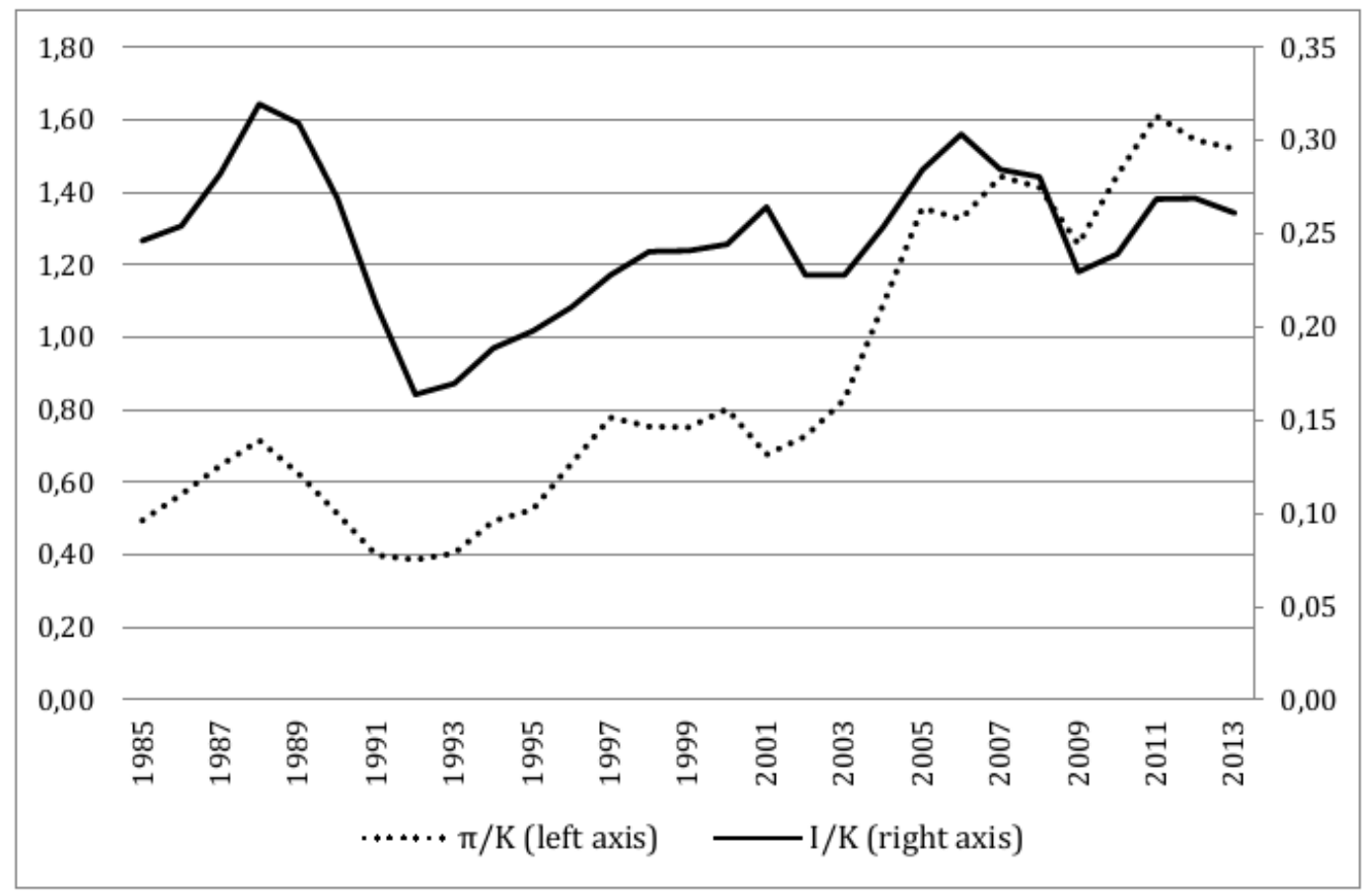

Source: Authors' calculation based on Worldscope data

Figure 4. Investment/Operating income $(I / \pi)$, and financial assets/fixed assets $(F A / K)$ in NFCs, the UK

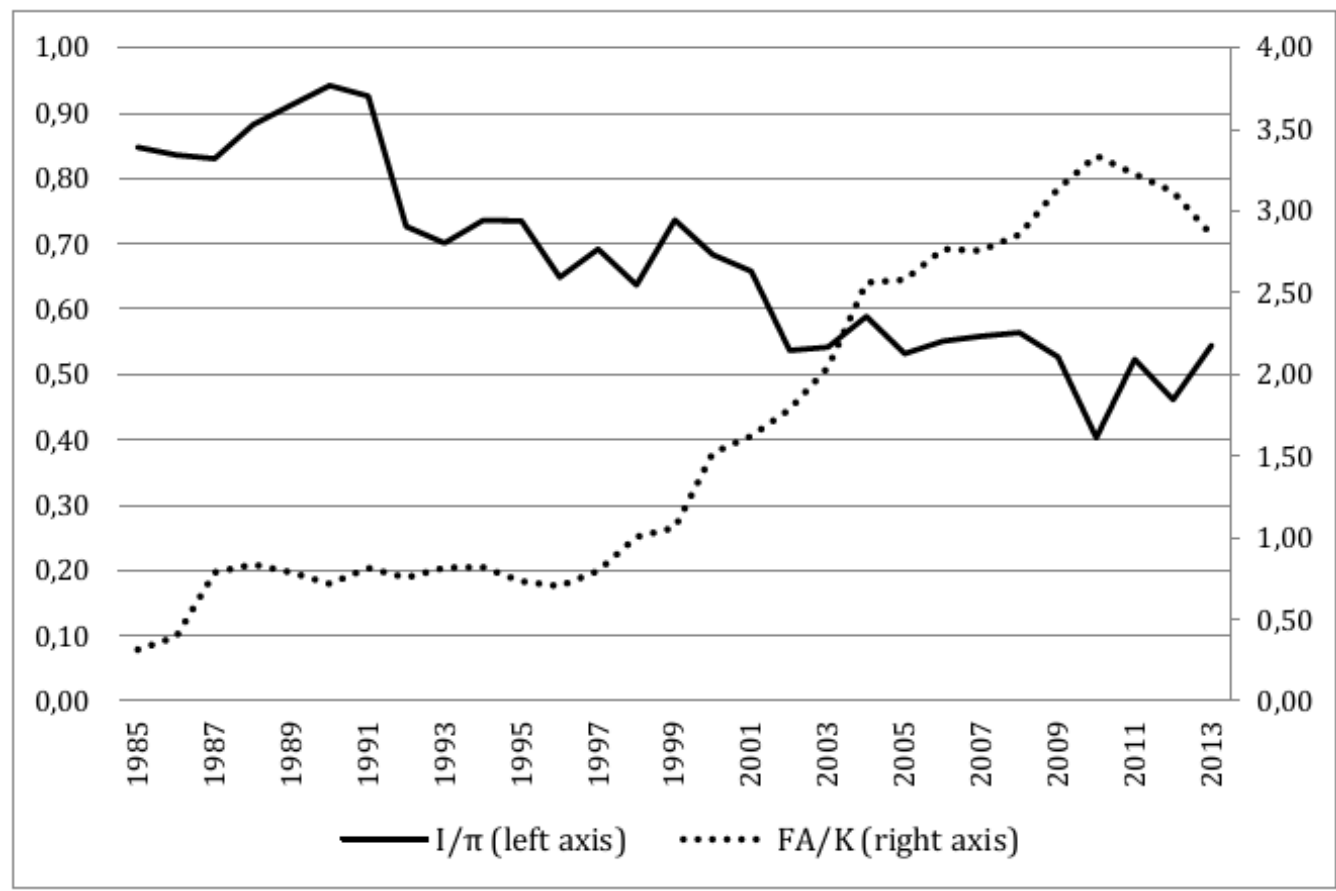

Source: authors' calculation based on Worldscope data. 
Figure 5. Investment/Operating income $(I / \pi)$, and non-operating income $\left(\pi_{F} / K\right)$ in NFCs, the UK

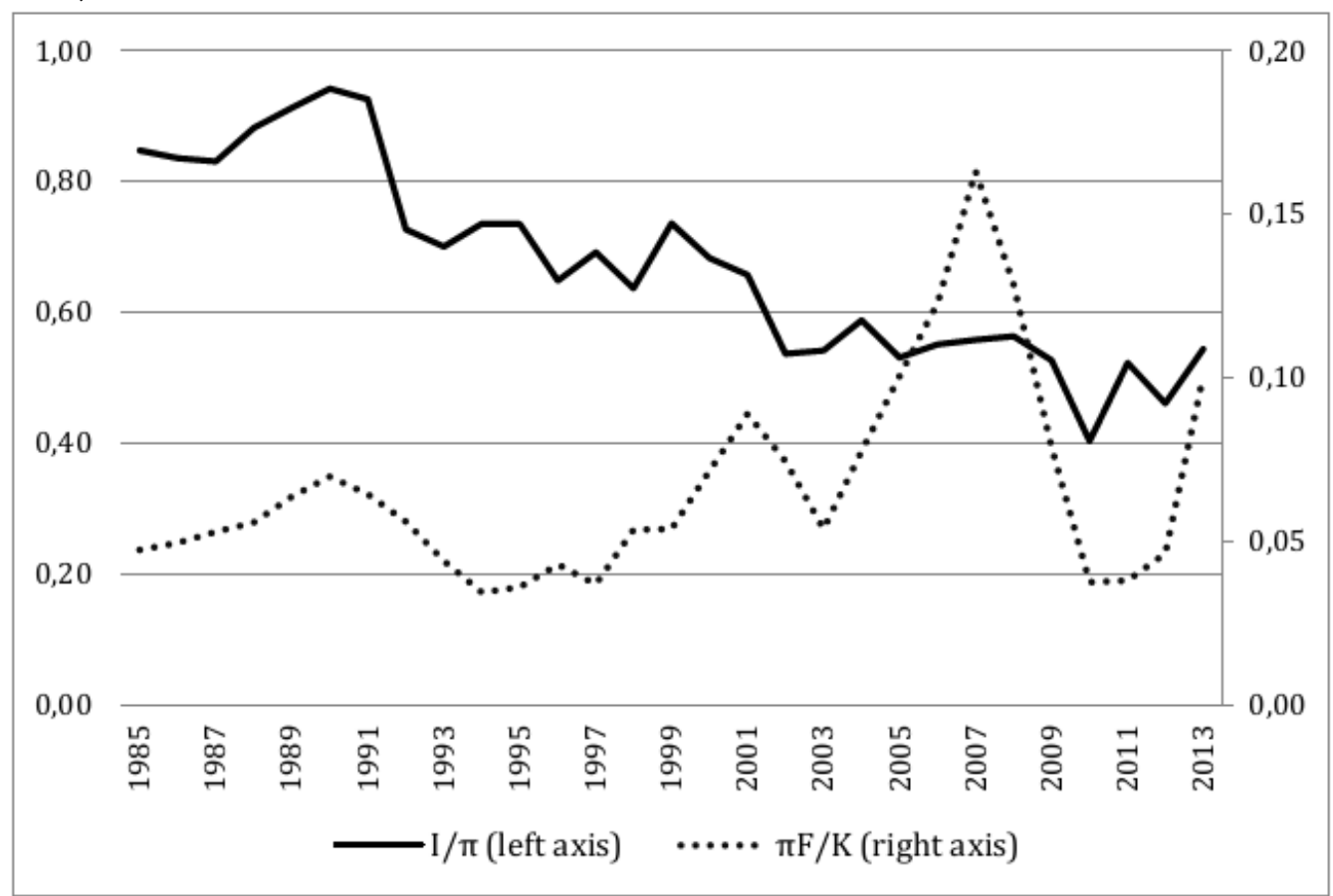

Source: authors' calculation based on Worldscope data.

Figure 6. Cash dividends/fixed assets $(C D / K)$, and interest paid on debt $\left(i_{D} / K\right)$ in the NFCs, the UK

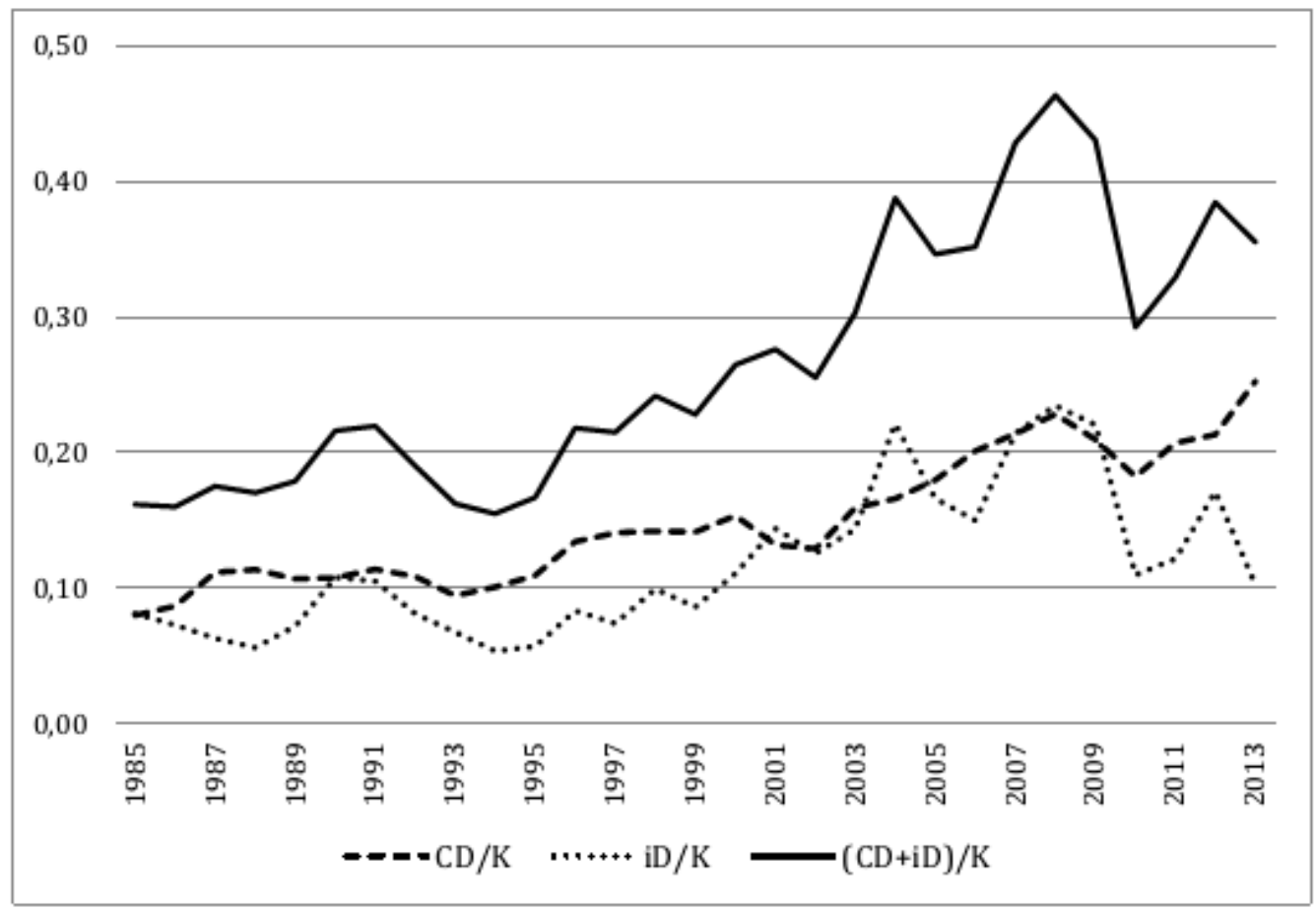

Source: authors' calculation based on Worldscope data. 
Table 1. Estimation results based on Models (1), (2), (3), and (4); dependent variable $(I / K)_{t}$; Estimation period $1985-2013$

\begin{tabular}{|c|c|c|c|c|c|c|}
\hline Variable & $(1)^{\mathrm{I}}$ & $(2)^{I I}$ & $(3)^{\mathrm{III}}$ & $(4)^{\mathrm{IV}}$ & $(5)^{v}$ & $(6)^{\mathrm{VI}}$ \\
\hline$(I / K)_{t-1}$ & $\begin{array}{c}0.366 \star \star \star \\
(0.028)\end{array}$ & $\begin{array}{c}0.343 * * * \\
(0.028)\end{array}$ & $\begin{array}{c}0.410 \star \star \star \\
(0.037)\end{array}$ & $\begin{array}{c}0.374 * \star * \\
(0.033)\end{array}$ & $\begin{array}{c}0.353 \star \star \star \\
(0.033)\end{array}$ & $\begin{array}{c}0.383 * * * \\
(0.032)\end{array}$ \\
\hline$[(\pi-C D) / K]_{t-1}$ & $\begin{array}{c}0.086 \star \star \star \\
(0.014)\end{array}$ & $\begin{array}{c}0.094 \star \star \star \\
(0.012)\end{array}$ & $\begin{array}{c}0.092 \star \star \star \\
(0.015)\end{array}$ & $\begin{array}{c}0.081 \star \star \star \\
(0.014)\end{array}$ & $\begin{array}{c}0.071 \star \star \star \\
(0.014)\end{array}$ & $\begin{array}{c}0.079 \star \star \star \\
(0.014)\end{array}$ \\
\hline$[(\pi-C D) / K]_{t-2}$ & $\begin{array}{l}-0.048 \star \star \\
(0.022)\end{array}$ & & & & & \\
\hline$(S / K)_{t-1}$ & $\begin{array}{c}0.267 \star \star \star \\
(0.052)\end{array}$ & $\begin{array}{c}0.256 \star \star \star \\
(0.049)\end{array}$ & $\begin{array}{l}0.209 \star \star \star \\
(0.059)\end{array}$ & $\begin{array}{c}0.277 \star \star \star \\
(0.050)\end{array}$ & $\begin{array}{c}0.278 \star \star \star \\
(0.051)\end{array}$ & $\begin{array}{c}0.263 \star \star * \\
(0.050)\end{array}$ \\
\hline$\left(i_{D} / K\right)_{t-1}$ & $\begin{array}{c}-0.056 * \star \star \\
(0.012)\end{array}$ & $\begin{array}{l}-0.058 \star \star \star \\
(0.012)\end{array}$ & $\begin{array}{l}-0.046 \star \star \star \\
(0.014)\end{array}$ & & & \\
\hline$(C D / K)_{t-2}$ & & $\begin{array}{c}-0.030 \star \star \\
(0.013)\end{array}$ & $\begin{array}{l}-0.017 \\
(0.014)\end{array}$ & & & \\
\hline$(F / K)_{t-1}$ & & & & $\begin{array}{c}-0.058 \star \star \star \star \\
(0.018)\end{array}$ & $\begin{array}{c}-0.052 \star \star \star \\
(0.018)\end{array}$ & $\begin{array}{c}-0.060 \star \star \star \\
(0.017)\end{array}$ \\
\hline$\left(\pi_{F} / K\right)_{t-2}$ & & & $\begin{array}{c}-0.034 \star \\
(0.018)\end{array}$ & $\begin{array}{c}-0.030 \star \\
(0.017)\end{array}$ & $\begin{array}{r}-0.031 \star \\
(0.017)\end{array}$ & $\begin{array}{c}-0.020 * * \\
(0.009)\end{array}$ \\
\hline$\left(\pi_{F} / K\right) * D_{25, t-1}$ & & & & & & $\begin{array}{c}0.131 * * * \\
(0.034)\end{array}$ \\
\hline$(Q)_{t-1}$ & & & & & $\begin{array}{r}0.116 \star * \\
(0.053) \\
\end{array}$ & \\
\hline Number of Observations & 11057 & 9850 & 7247 & 9224 & 9061 & 8923 \\
\hline Number of Firms & 1338 & 1172 & 989 & 1195 & 1184 & 1158 \\
\hline Number of Instruments & 34 & 36 & 36 & 36 & 38 & 38 \\
\hline$p$-value Arellano-Bond test (AR2) & 0.850 & 0.250 & 0.070 & 0.114 & 0.079 & 0.096 \\
\hline$p$-value Hansen test & 0.962 & 0.570 & 0.687 & 0.545 & 0.259 & 0.767 \\
\hline $\begin{array}{l}\text { Time effects } \\
p \text {-value } \text { Wald test for time effects }\end{array}$ & $\begin{array}{c}\text { yes } \\
0.000\end{array}$ & $\begin{array}{c}\text { Yes } \\
0.000\end{array}$ & $\begin{array}{c}\text { Yes } \\
0.000\end{array}$ & $\begin{array}{c}\text { yes } \\
0.000\end{array}$ & $\begin{array}{c}\text { yes } \\
0.000\end{array}$ & $\begin{array}{c}\text { Yes } \\
0.000\end{array}$ \\
\hline
\end{tabular}

All estimations I, II, III, and IV are based on Equations (1),(2),(3), and (4) respectively. Estimation V is based on Equation (4) plus Tobin's Q. Estimation VI is based on Equation (4), with separate effect estimated for companies in the upper 75 percentile vs. the ones in the 25 lower percentile in terms of total assets. Two-step difference-GMM estimations. Coefficients for the year dummies are not reported. Robust corrected standard errors in parenthesis. * significant at $10 \% ; \star \star$ significant at $5 \% ; \star \star \star$ significant at $1 \%$. 
Table 2. Estimation results based on Model (4) for different time periods, sectors, and sample; dependent variable $(I / K)_{t}$

\begin{tabular}{|c|c|c|c|c|}
\hline Variable & $\begin{array}{c}(1)^{\mathrm{I}} \\
1985-2007\end{array}$ & $\begin{array}{c}(2)^{\text {II }} \\
1992-2007\end{array}$ & $\begin{array}{c}(3)^{\text {III }} \\
\text { Raw-sample }\end{array}$ & $\begin{array}{c}\text { (4) })^{\mathrm{IV}} \\
\text { Excluding } \\
\text { Public Utilities, } \\
\text { Transportation, } \\
\text { and Services }\end{array}$ \\
\hline$(I / K)_{t-1}$ & $\begin{array}{l}0.388 * * \star \\
(0.037)\end{array}$ & $\begin{array}{c}0.383 \star \star \star \\
(0.036)\end{array}$ & $\begin{array}{c}0.349 * * * \\
(0.031)\end{array}$ & $\begin{array}{c}0.355 * \star \star \\
(0.031)\end{array}$ \\
\hline$[(\pi-C D) / K]_{t-1}$ & $\begin{array}{l}0.083 * k \star \\
(0.017)\end{array}$ & $\begin{array}{l}0.083 * \star \star \\
(0.017)\end{array}$ & $\begin{array}{l}0.079 * * * \\
(0.013)\end{array}$ & $\begin{array}{l}0.069 * * \star \\
(0.014)\end{array}$ \\
\hline$(S / K)_{t-1}$ & $\begin{array}{c}0.217 * \star \star \\
(0.060)\end{array}$ & $\begin{array}{c}0.213 \star \star \star \\
(0.061)\end{array}$ & $\begin{array}{l}0.264 * * \star \\
(0.066)\end{array}$ & $\begin{array}{c}0.275 * k * \\
(0.051)\end{array}$ \\
\hline$(F / K)_{t-1}$ & $\begin{array}{c}-0.082 \star k * \\
(0.025)\end{array}$ & $\begin{array}{c}-0.095 * \star \star \\
(0.025)\end{array}$ & $\begin{array}{l}-0.051 * \star \\
(0.020)\end{array}$ & $\begin{array}{c}-0.065 * k * \\
(0.019)\end{array}$ \\
\hline$\left(\pi_{F} / K\right)_{t-2}$ & $\begin{array}{c}-0.067 \star * * \\
(0.020) \\
\end{array}$ & $\begin{array}{c}-0.069 * \star \star \\
(0.020)\end{array}$ & $\begin{array}{c}-0.038 * * \\
(0.017)\end{array}$ & $\begin{array}{c}-0.033 \star \\
(0.017) \\
\end{array}$ \\
\hline Number of Observations & 6882 & 6637 & 10081 & 8381 \\
\hline Number of Firms & 1061 & 1048 & 1371 & 1080 \\
\hline Number of Instruments & 30 & 27 & 36 & 36 \\
\hline$p$-value A-B test (AR2) & 0.257 & 0.178 & 0.065 & 0.102 \\
\hline$p$-value Hansen test & 0.498 & 0.458 & 0.180 & 0.718 \\
\hline Time effects & yes & yes & yes & yes \\
\hline $\begin{array}{l}p \text {-value Wald test for time } \\
\text { effects }\end{array}$ & 0.000 & 0.000 & 0.000 & 0.000 \\
\hline
\end{tabular}

I Specification based on Equation (4) period 1985-2007, II specification based on Equation (4) period 19912007, III specification based on Equation (4) using the raw sample, IV specification based on Equation (4) by excluding companies in the public sectors (utilities and services). Two-step difference-GMM estimations. Coefficients for the year dummies are not reported. Robust corrected standard errors in parenthesis. * significant at $10 \% ; \star \star$ significant at $5 \% ; \star \star \star *$ significant at $1 \%$.

Table 3. Estimation results based on Model (4) for the manufacturing sector; dependent variable $(I / K)_{t}$

\begin{tabular}{|c|c|c|c|}
\hline Variable & $\begin{array}{c}(1)^{\mathrm{I}} \\
1985-2013\end{array}$ & $\begin{array}{c}(2)^{\text {II }} \\
1985-2007\end{array}$ & $\begin{array}{c}(3)^{\mathrm{III}} \\
1991-2007\end{array}$ \\
\hline$(I / K)_{t-1}$ & $\begin{array}{c}0.347 \star \star \star \\
(0.040)\end{array}$ & $\begin{array}{c}0.364 \star \star \star \\
(0.045)\end{array}$ & $\begin{array}{c}0.364 \star \star \star \\
(0.044)\end{array}$ \\
\hline$[(\pi-C D) / K]_{t-1}$ & $\begin{array}{c}0.047 \star \star \star \\
(0.018)\end{array}$ & $\begin{array}{l}0.032 \star \\
(0.019)\end{array}$ & $\begin{array}{l}0.033 \star \\
(0.020)\end{array}$ \\
\hline$(S / K)_{t-1}$ & $\begin{array}{c}0.311 \star \star \star \\
(0.098)\end{array}$ & $\begin{array}{l}0.212 \star \\
(0.110)\end{array}$ & $\begin{array}{l}0.171 \star \\
(0.103)\end{array}$ \\
\hline$(F / K)_{t-1}$ & $\begin{array}{l}-0.115 \star \star \star \\
(0.037)\end{array}$ & $\begin{array}{c}-0.163 \star \star \star \\
(0.038)\end{array}$ & $\begin{array}{c}-0.173 \star \star \star \\
(0.042)\end{array}$ \\
\hline$\left(\pi_{F} / K\right)_{t-2}$ & $\begin{array}{c}-0.051 \star \star \star \\
(0.024) \\
\end{array}$ & $\begin{array}{c}-0.088 * \star \star \\
(0.028) \\
\end{array}$ & $\begin{array}{c}-0.085 * \star \star \\
(0.028) \\
\end{array}$ \\
\hline Number of Observations & 3700 & 2875 & 2792 \\
\hline Number of Firms & 456 & 424 & 420 \\
\hline Number of Instruments & 36 & 30 & 27 \\
\hline$p$-value $\mathrm{A}$-B test (AR2) & 0.261 & 0.188 & 0.152 \\
\hline$p$-value Hansen test & 0.364 & 0.629 & 0.728 \\
\hline Time effects & yes & yes & yes \\
\hline$p$-value Wald test for time effects & 0.000 & 0.000 & 0.000 \\
\hline
\end{tabular}

I specification based on Equation (4) for the manufacturing sector, II specification based on Equation (4) the manufacturing sector for period 1985-2007, III specification based on Equation (4) the manufacturing sector for period 1991-2007. Two-step difference-GMM estimations. Coefficients for the year dummies are not reported. Robust corrected standard errors in parenthesis. * significant at $10 \% ; \star \star$ significant at $5 \% ; \star \star \star$ significant at $1 \%$. 
Table 4. Economic effects based on estimation results in Table 1, Table 2, and Table 3

\begin{tabular}{|c|c|c|c|c|c|c|}
\hline \multicolumn{7}{|c|}{ ALL SECTORS } \\
\hline \multirow[t]{2}{*}{ Variable } & $\begin{array}{l}\text { Long-run } \\
\text { coefficient }\end{array}$ & $\begin{array}{c}\text { Actual } \\
\text { cumulative } \\
\text { change }\end{array}$ & $\begin{array}{c}\text { Economic } \\
\text { effect }\end{array}$ & $\begin{array}{l}\text { Long-run } \\
\text { coefficient }\end{array}$ & $\begin{array}{c}\text { Actual } \\
\text { cumulative } \\
\text { change }\end{array}$ & $\begin{array}{c}\text { Economic } \\
\text { effect }\end{array}$ \\
\hline & \multicolumn{3}{|c|}{$1985-2013$} & \multicolumn{3}{|c|}{$1985-2007$} \\
\hline$(\pi-C D) / K$ & 0.129 & 0.741 & 0.096 & 0.136 & 0.831 & 0.113 \\
\hline$S / K$ & 0.442 & 1.082 & 0.479 & 0.355 & 1.031 & 0.366 \\
\hline$F / K$ & -0.093 & 0.917 & -0.085 & -0.134 & 0.849 & -0.114 \\
\hline$\pi_{F} / K$ & -0.048 & 0.751 & -0.036 & -0.109 & 1.233 & -0.135 \\
\hline \multicolumn{7}{|c|}{ MANUFACTURING } \\
\hline$(\pi-C D) / K$ & 0.072 & 0.586 & 0.042 & 0.050 & 0.876 & 0.044 \\
\hline$S / K$ & 0.476 & 0.791 & 0.377 & 0.333 & 0.756 & 0.252 \\
\hline$F / K$ & -0.176 & 0.766 & -0.135 & -0.256 & 0.771 & -0.198 \\
\hline$\pi_{F} / K$ & -0.078 & -1.303 & 0.102 & -0.138 & 0.654 & -0.091 \\
\hline
\end{tabular}

All the results are based on estimations of Model (4). The long-run coefficient is equal to the estimated coefficient for the variable divided by 1 minus the coefficient of the lagged dependent variable. The economic effect is obtained by multiplying the long-run coefficient with the actual cumulative change of the variable. 


\section{Appendices}

Table 1A. Variables definition and codes.

\begin{tabular}{|c|c|c|c|}
\hline Symbol & Variable & Definition & $\begin{array}{c}\text { Worldscope } \\
\text { Code }\end{array}$ \\
\hline$I$ & Investment & Addition to fixed assets & WC04601 \\
\hline$K$ & Capital Stock & Net fixed capital stock & WC02501 \\
\hline$S$ & Sales & Net sales & WC01001 \\
\hline$\pi$ & Profit & Operating income & WC01250 \\
\hline$i_{D}$ & Interests paid & Interest expenses on debt & WC01251 \\
\hline$C D$ & $\begin{array}{l}\text { Dividends } \\
\text { paid }\end{array}$ & Cash dividends paid & WC04551 \\
\hline$\pi_{F}$ & $\begin{array}{l}\text { Financial } \\
\text { profit }\end{array}$ & $\begin{array}{l}\text { Non-operating income from } \\
\text { interests and dividends }\end{array}$ & WC01266 + WC01268 \\
\hline$Q$ & $\begin{array}{l}\text { Average } \\
\text { Tobin's Q }\end{array}$ & $\begin{array}{l}\text { (Market share price }{ }^{*} \\
\text { common share outstanding + } \\
\text { total liabilities)/total assets }\end{array}$ & $\frac{W C 08001+W C 03351}{W C 02999}$ \\
\hline$F A$ & $\begin{array}{l}\text { Financial } \\
\text { Assets }\end{array}$ & $\begin{array}{c}\text { Cash, other investment, short- } \\
\text { term investment, other } \\
\text { current assets }\end{array}$ & $\begin{array}{c}\text { WC02003+ WC02250+ } \\
\text { WC02008+ } \\
\text { WC0214 }\end{array}$ \\
\hline
\end{tabular}

Table 2A. Correlations between ONS macroeconomic data and Worldscope sample data.

\begin{tabular}{ccc}
\hline Variable & $\begin{array}{c}\text { Correlations } \\
1997-2013\end{array}$ & $\begin{array}{c}\text { Correlations } \\
1997-2007\end{array}$ \\
\hline$K$ & 0.86 & 0.74 \\
$S$ & 0.94 & 0.91 \\
$i_{D}$ & 0.75 & 0.77 \\
$C D$ & 0.18 & 0.73 \\
Interest income & 0.91 & 0.83 \\
Dividend income & -0.54 & 0.57 \\
\hline
\end{tabular}

Macroeconomic data from ONS, United Kingdom Economic Account. Available at http//www.ons.gov.uk/ons/rel/naalrd/united-kingdom-economic-accounts/index.html_(last accessed 27/04/2015). 
Table 3A. Summary statistics, NFCs, the UK; all sectors

\begin{tabular}{|c|c|c|c|c|c|c|}
\hline Variable & Mean & & Std. dev. & Min. & Max. & Observations \\
\hline$(I / K)$ & 0.246 & $\begin{array}{l}\text { overall } \\
\text { between } \\
\text { within }\end{array}$ & $\begin{array}{l}0.202 \\
0.164 \\
0.149\end{array}$ & $\begin{array}{r}0 \\
0.003 \\
-0.707 \\
\end{array}$ & $\begin{array}{c}1.5 \\
1.295 \\
1.490 \\
\end{array}$ & $\begin{array}{cr}N= & 21265 \\
n= & 1732 \\
T-\text { bar } & =12.3\end{array}$ \\
\hline$(S / K)$ & 11.894 & $\begin{array}{c}\text { overall } \\
\text { between } \\
\text { within }\end{array}$ & $\begin{array}{l}20.494 \\
21.203 \\
11.232\end{array}$ & $\begin{array}{r}0.0983 \\
0.107 \\
-75.392 \\
\end{array}$ & $\begin{array}{l}177.082 \\
174.737 \\
150.924 \\
\end{array}$ & $\begin{array}{cr}N= & 20838 \\
n= & 1719 \\
T-\text { bar }= & 12.1\end{array}$ \\
\hline$(\pi-C D / K)$ & 0.568 & $\begin{array}{l}\text { overall } \\
\text { between } \\
\text { within }\end{array}$ & $\begin{array}{l}1.078 \\
1.141 \\
0.678 \\
\end{array}$ & $\begin{array}{l}-0.860 \\
-0.324 \\
-4.450 \\
\end{array}$ & $\begin{array}{l}8.334 \\
8.132 \\
7.944 \\
\end{array}$ & $\begin{array}{cr}N= & 20250 \\
n= & 1711 \\
T-\text { bar }= & 11.8\end{array}$ \\
\hline$\left(\pi_{F} / K\right)$ & 0.068 & $\begin{array}{l}\text { overall } \\
\text { between } \\
\text { within }\end{array}$ & $\begin{array}{l}0.359 \\
0.251 \\
0.301\end{array}$ & $\begin{array}{r}0 \\
0 \\
-3.186\end{array}$ & $\begin{array}{c}28.891 \\
5.667 \\
25.706\end{array}$ & $\begin{array}{cr}N= & 18405 \\
n= & 1609 \\
T-b a r= & 11.4\end{array}$ \\
\hline$(F / K)$ & 0.280 & $\begin{array}{l}\text { overall } \\
\text { between } \\
\text { within }\end{array}$ & $\begin{array}{l}0.451 \\
0.397 \\
0.291\end{array}$ & $\begin{array}{r}0 \\
0 \\
-1.801\end{array}$ & $\begin{array}{l}3.461 \\
3.019 \\
3.363\end{array}$ & $\begin{array}{cr}N= & 21052 \\
n= & 1726 \\
T-\text { bar }= & 12.2\end{array}$ \\
\hline$(Q)$ & 1.518 & $\begin{array}{l}\text { overall } \\
\text { between } \\
\text { within }\end{array}$ & $\begin{array}{l}0.874 \\
0.639 \\
0.640\end{array}$ & $\begin{array}{r}0.361 \\
0.391 \\
-1.692 \\
\end{array}$ & $\begin{array}{l}6.700 \\
6.502 \\
6.311 \\
\end{array}$ & $\begin{array}{cr}N= & 21254 \\
n= & 1732 \\
T-b a r= & 12.3\end{array}$ \\
\hline
\end{tabular}

Source: authors' calculation based on Worldscope data

$N=$ number of total observations, $n=$ number of groups, $T$ - $b a r=$ average time period

Table 4A. Summary statistics, NFCs, the UK; manufacturing sector

\begin{tabular}{|c|c|c|c|c|c|c|}
\hline Variable & Mean & & Std. dev. & Min. & Max. & Observations \\
\hline$(I / K)$ & 0.211 & $\begin{array}{l}\text { overall } \\
\text { between } \\
\text { within }\end{array}$ & $\begin{array}{l}0.161 \\
0.116 \\
0.127\end{array}$ & $\begin{array}{r}0 \\
0.005 \\
-0.434 \\
\end{array}$ & $\begin{array}{c}1.5 \\
0.932 \\
1.455 \\
\end{array}$ & $\begin{array}{cr}N= & 8267 \\
n= & 615 \\
T-b a r= & 13.4\end{array}$ \\
\hline$(S / K)$ & 7.186 & $\begin{array}{l}\text { overall } \\
\text { between } \\
\text { within }\end{array}$ & $\begin{array}{r}10.889 \\
9.773 \\
7.029\end{array}$ & $\begin{array}{r}0.102 \\
0.107 \\
-44.204\end{array}$ & $\begin{array}{c}159.9 \\
72.615 \\
133.952\end{array}$ & $\begin{array}{rr}N= & 8237 \\
n= & 614 \\
T-b a r= & 13.4\end{array}$ \\
\hline$(\pi-C D / K)$ & 0.413 & $\begin{array}{l}\text { overall } \\
\text { between } \\
\text { within }\end{array}$ & $\begin{array}{l}0.758 \\
0.762 \\
0.520\end{array}$ & $\begin{array}{l}-0.853 \\
-0.132 \\
-3.795\end{array}$ & $\begin{array}{l}8.182 \\
7.742 \\
7.315\end{array}$ & $\begin{array}{cr}N= & 8087 \\
n= & 614 \\
T-b a r= & 13.2\end{array}$ \\
\hline$\left(\pi_{F} / K\right)$ & 0.043 & $\begin{array}{l}\text { overall } \\
\text { between } \\
\text { within }\end{array}$ & $\begin{array}{l}0.171 \\
0.134 \\
0.122\end{array}$ & $\begin{array}{r}0 \\
0 \\
-1.365\end{array}$ & $\begin{array}{c}5 \\
2 \\
4.184\end{array}$ & $\begin{array}{rr}N= & 7049 \\
n= & 577 \\
T-b a r= & 12.2\end{array}$ \\
\hline$(F / K)$ & 0.225 & $\begin{array}{l}\text { overall } \\
\text { between } \\
\text { within }\end{array}$ & $\begin{array}{l}0.323 \\
0.265 \\
0.219 \\
\end{array}$ & $\begin{array}{r}0 \\
0 \\
-1.308 \\
\end{array}$ & $\begin{array}{l}3.461 \\
2.815 \\
3.138 \\
\end{array}$ & $\begin{array}{cr}N= & 8230 \\
n= & 615 \\
T-b a r= & 13.4\end{array}$ \\
\hline$(Q)$ & 1.510 & $\begin{array}{l}\text { overall } \\
\text { between } \\
\text { within }\end{array}$ & $\begin{array}{l}0.833 \\
0.632 \\
0.588\end{array}$ & $\begin{array}{r}0.364 \\
0.440 \\
-1.699\end{array}$ & $\begin{array}{l}6.687 \\
6.502 \\
6.304\end{array}$ & $\begin{array}{cr}N= & 8252 \\
n= & 614 \\
T-b a r= & 13.4\end{array}$ \\
\hline
\end{tabular}

Source: authors' calculation based on Worldscope data

$N=$ number of total observations, $n=$ number of groups, $T$ - bar $=$ average time period 


\section{Endnotes}

1 According to Van der Zwan (2014:114) “Corporate governance reform often came slightly later and partially as a response to financial market liberalization. The UK was an early mover, where shareholderoriented corporate governance institutions were developed both through law and self-regulatory codes regarding the structure and duties of boards. Other countries followed with measures to strengthen shareholder rights and deregulate the use of corporate equity."

${ }^{2}$ According to Lapavitsas and Powell (2013:375) "the evidence indicated that, in all countries, nonfinancial corporations have become less reliant on banks and have increased their acquisition of financial assets. However, there is variation in the trend, Japanese and German lagging behind US and UK enterprises."

${ }^{3}$ In contrast, some authors of the Marxian tradition (e.g. Lapavitsas, 2009; Kliman and Williams, 2014) argue for a reversed causality, i.e. financialization of the economy should be understood as a consequence, and not as a cause of the slowdown in the capital accumulation.

${ }^{4}$ The paper provides a response to the mainstream critiques of the use of liquidity measures to model investment by Jorgenson (1971).

${ }^{5}$ Variables definitions are in Appendix Table1A. In our version of the model by Fazzari and Mott (1986) we add the lagged rate of accumulation as an additional explanatory variable. Secondly, we do not need a variable for the gross plant value, since we already control for the companies' size by scaling each variable as a ratio to fixed capital.

${ }^{6}$ Following the agreed accounting definition, 'non-operating income' is the portion of an organization's income that is derived from activities not related to its core operations. This type of income usually consists of dividend income, profits and losses from investments and currency exchange rate dynamics, plus other non-operating revenues. As shown in Table $1 \mathrm{~A}$ in the appendix, the two variables that constitute the aggregate financial profit are dividends and interests received by the company. This is also consistent with the way aggregate financial payments are defined. Interest and dividends do not exhaust the spectrum of nonoperating financial incomes of NFCs. In fact Krippner (2005) shows how capital gains account for a considerable part of NFCs financial profits. However, as recognised by Orhangazi (2008b) with respect to Compustat database, also in Worldscope data on capital gains are not available. 
${ }^{7}$ We also extended the model with total debt/fixed capital, and change in or the square of this ratio, but we did not find any statistically significant effects. Results are available upon request. An extended model with share buybacks was not feasible due to lack of data. In fact, Worldscope does not provide sufficient number of observations about companies' share buybacks in the UK. The inclusion of this variable would have caused a considerable reduction in our sample, in terms of both the number of firms and the time period. In addition to this technical reason, we believe that the process of share buybacks could be viewed also as a method for the financial managers of the firms to modify the capital structure of the organization and not always as a way to artificially raise the price of the share.

${ }^{8}$ Standard Industry Classification (SIC) code, 1994 version.

${ }^{9}$ The choice of the time-period is due to data availability.

${ }^{10}$ We compare our sample with data from the Office for National Statistics (ONS) in Appendix Table2A. Macro data for detailed variables are available only for 1997-2013. ONS does not provide a disaggregation for publicly listed and private companies.

${ }^{11}$ We follow Chirinko et al. (1999) and Orhangazi (2008b) for defining the outliers. Our estimations are robust to the inclusion of the outliers.

${ }^{12}$ The ratio of operating income to $\mathrm{K}$ appears to be rather high. This is because physical assets $(\mathrm{K})$ are only $32.8 \%$ of total assets including financial assets on average over the whole period and all firms. Total operating and non-operating income as a ratio to total assets would be $10.3 \%$ on average.

${ }^{13}$ Milberg and Winkler (2009) argue that the accumulation-financialization link is blurred by the increase in off-shoring. This is not a problem in our case, since all our data are provided on a consolidated basis (parent company plus subsidiaries). Moreover, the non-operating dividend incomes come from financial activities. ${ }^{14}$ The full period is 29 years, but the average period for which all the variables are available is 6-9 years.

15 Hansen test takes the orthogonality between instruments and regressions' residuals as the indicator of consistency between estimated and sample moments. We tested and confirmed the presence of heteroskedasticity in our sample by using the White/Koenker and the Breusch-Pagan/Godfrey/CookWeisberg tests. Hansen's-J test is preferred to the Sargan test in the presence of heteroskedasticity (Roodman, 2009). However, the Hansen test (as the Sargan test) is sensitive to the total number of 
instruments. Therefore, we use only the first and second lags of our variables as instruments. Furthermore, all instruments are 'collapsed', thus having an instrument for each variable and lag distance.

${ }^{16}$ We use the approximate average measure for Tobin's Q suggested by Chung and Pruitt (1994:71), who define it as a compromise between "analytical precision and computational effort" based on the wellestablished procedure by Lindenberg and Ross (1981). Tobin's Q is treated as endogenous based on the Hansen-test.

${ }^{17}$ Furthermore, we checked the robustness of our results by excluding firms with a logarithmic change in sales higher than 1 (only 5 firms excluded). The estimated coefficients are robust.

${ }^{18}$ The economic effects for 1992-2007 are very similar to the 1985-2007. Results are available upon request.

${ }^{19}$ The actual change of financial incomes is positive even if we take into account the crisis. This is due to the recovery of interest and dividends incomes since 2009. 